\title{
Pengaruh Sentra Bahan Alam Terhadap Kemampuan Sains Anak Pada Kelompok B Ra Roudlotul Mujtahidin Jrambe Kecamatan Dlanggu Kabupaten Mojokerto
}

\author{
Putri Ismawati, M.Pd., Iisnawati, S.Pd. \\ putriismawati.pi@gmail.com., iisnawati815@gmail.com. \\ Dosen PIAUD STITNU Al Hikmah Mojokerto
}

\begin{abstract}
ABSTRAK
Penelitian ini bertujuan untuk meningkatkan kemampuan sains anak Kelompok B RA Roudlotul Mujtahidin Desa Jrambe Kecamatan Dlanggu Mojokerto melalui Sentra Bahan Alam.Penelitian ini menggunakan metode penelitian kuantitatif dengan jenis penelitiannya adalah penelitian Eksperimen. Penelitian ini menggunakan desain penelitian PreExperimental Designs dengan menggunakan One-Group Pre-Test-Post-Test Designs.

Nilai peningkatan perkembangan Kemampuan Sains dari ke 26 siswa yang telah dilakukan penerapan pembelajaran Sentra Bahan Alam rata-rata skor atau nilai meningkat 13.50. Test Statistics diatas nilai Asymp. Sig (2-tailed) adalah 0, Karena nilai Asymp. Sig (2tailed) lebih kecil dari 0.005 maka ada pengaruh yang signifikan perkembangan Kemampuan Sains anak sebelum dan sesuadah penerapan pembelajaran Sentra Bahan Alam. Dilihat dari hasil analisis angka-angka statistik yang dihasilkan melalui Uji Wilcoxon hasilnya adalah bahwa Penerapan Pembelajaran Sentra Bahan Alam berpengaruh terhadap peningkatan perkermbangan Kemampuan Sains anak di RA Roudlotul Mujtahidin Jrambe. Pembelajaran Sentra Bahan Alam sangat efektif untuk meningkatkan perkembangan Kemampuan Sains anak khusunya
\end{abstract}

Kata-kata Kunci: Bahan Alam, kemampuan sains, kognitif

\section{ABSTRACT}

This study aims to improve the ability of children science Group B RA Roudlotul Mujtahidin Jrambe Village District Dlanggu Mojokerto through Sentra Bahan Alam.Penelitian using quantitative research methods with the type of research is experimental research. This research uses Pre-Experimental Designs research design using One-Group Pre-Test-Post-Test Designs.

The value of improvement of the Science Ability of the 26 students who have done the application of learning Material Sentra Nature average score or value increased 13.50. Test Statistics above Asymp value. Sig (2-tailed) is 0, Because the value of Asymp. Sig (2-tailed) is smaller than 0.005 then there is a significant effect of the development of children's Science Skills before and after the application of learning Material Sentra Nature. Judging from the analysis of statistical figures generated through Wilcoxon Test, the result is that the Application of Learning Center of Natural Resources has an effect on increasing the ability of children Science in RA Roudlotul Mujtahidin Jrambe. Learning Center Natural Materials is very effective to improve the development of Science Capabilities of children especially

Key Words: Nature Materials, scientific ability, cognitive 


\section{PENDAHULUAN}

Pendidikan sejak dini sangatlah penting pada anak usia dini untuk mempersiapkan generasi yang memumpuni pada suatu bangsa. Di dalam penelitian bidang psikologi yang dilakukan oleh National Association for the Educational of Young Children (NAEYC) ${ }^{1}$ (Mahyudin 2015:15) menunjukkan, bila anak distimulasi sejak dini, maka akan ditemukan genius (potensi paling unggul) dalam dirinya. Setiap anak memiliki kemampuan tak terbatas dalam belajar (Limitless Capacity to Learn) yang intern (telah ada) dalam dirinya untuk berfikir kreatif dan produktif.

Untuk mengetahui tumbuh kembang anak baik dalam Kognitif, Afektif dan Psikomotoriknya maka kita perlu mengidentifikasi pola aktifitasnya dengan memberikan berbagaim rangsangan untuk dapat belajar sendiri sesuai dengan perkembangannya tanpa ada unsur penghalang maupun punishment (hukuman) dan memperbanyak reivocement (dukungan).

Lembaga TK/RA merupakan salah satu bentuk layanan pendidikan bagi anak usia dini yaitu sekitar usia tiga sampai memasuki tahap pendidikan dasar. Pendidikan diarahkan untuk mengembangkan potensi anak seoptimal mungkin sesuai dengan tahap tumbuh kembang anak melalui kegiatan bermain sambil belajar. Hal tersebut sesuai dengan Undang - Undang Dasar 1945 pasal 28C Ayat (2) Amandemen UUD 1945 yaitu setiap anak berhak mengembangkan diri melalui pemenuhan kebutuhan dasarnya, berhak mendapatkan pendidikan dan memeperoleh manfaat dari ilmu pengetahuan dan teknologi, seni, budaya, demi meningkatkan kualitas hidupnya dan demi kesejahteraan umat manusia. Yang kemudian di perjelas dengan bunyi UU No.20 tahun 2003 tentang Sistem Pendidikan Nasional pasal 28 ayat (3) yaitu pendidikan anak usia dini pada jalur pendidikan formal berbentuk Taman Kanak - Kanak, Raudhatul Atfal (RA), atau berbentuk lain sederajat.

Pendidikan Anak Usia Dini pembelajaran yang saat ini sedang dikembangkan adalah BCCT (Byond Centre and Circle Time) atau yang biasa disebut dengan sentra. Pendekatan sentra dan lingkaran adalah pendekatan penyelenggaraan PAUD yang berfokus pada anak dalam lingkaran dengan menggunakan 4 jenis pijakan (scaffolding) untuk mendukung perkembangan anak. "Setiap anak diperkenankan untuk memilih pusat kegiatan belajar yang akan digunakan untuk bereksplorasi dan bermain"2. Pembelajaran dengan menggunakan sentra lebih menyenangkan dibandingkan dengan klasikal. Karena sentra lebih menonjolkan kemampuan anak serta mengeksplor kemampuan anak dari pada klasikal yang lebih cenderung kepada gurunya yang aktif. Sentra yang ada di sekolah antara lain sentra persiapan, sentra bermain peran, sentra balok, sentra bahan alam, sentra seni dan kreativitas.

Sentra yang peneliti amati adalah sentra Bahan Alam. Karena pada sentra ini anak diajak untuk menyatu dengan alam, bermain sambil belajar. Menurut Hildayani (2015:56) mengatakan bahwa "Sentra alam merupakan sentra yang mengeksplor bahan-bahan yang tersedia di alam agar memungkinkan organ-organ sensori motorik anak bisa bekerja untuk mengenal, mengeksplorasi, dan menemukan pengetahuan atau konsep yang berkaitan dengan

\footnotetext{
${ }^{1}$ Martuti, Mengelola PAUD, (Yogjakarta: Kreasi Wacana, 2005), 15

${ }^{2}$ Ibid, 58
} 
benda benda disekitarnya"3. Dengan demikian data dikatakan bahwa sentra bahan alam sangat cocok digunakan untuk proses pembelajaran pada anak usia dini.

Kemampuan kognitif anak perlu dikembangkan karena kemampuan kognitif merupakan komponen yang sangat penting dalam perkembangan seorang anak. Hal ini sesuai dengan pendapat Vygotsky bahwa pertumbuhan kognitif seorang anak tidak semata-mata terjadi karena hubungannya dengan objek, namun yang paling pernting adalah hubungannya dengan orang lain". Peningkatan perkembangan kognitif anak dapat meningkat apabila anakanak dilibatkan dalam kegiatan-kegiatan yang menantang dan berarti tetapi tetap dalam pendampingan orang tua ${ }^{4}$.

Peneliti mengambil data dari RA Roudlotul Mujtahidin Jrambe untuk memenuhi tugas akhir perkuliahan. Sekolah ini dipilih karena lebih dekat dengan lingkungan tempat tinggal peneliti. Banyak murid di RA yang masih belum bisa berkembang dalam Kemampuan Sainsnya. Seperti contoh, masih ada beberapa anak yang masih belum mengenal tekstur, Ketika anak sedang melaksanakan kegiatan bermain sambil belajar di sentra bahan alam, ada beberapa anak yang belum bisa mengelompokan sayuran menurut warnanya. Kadang juga ada anak yang belum bisa membedakan ukuran besar kecil. Jadi dalam kaitannya hal tersebut, sentra bahan alam memiliki pengaruh terhadap Kemampuan Sains anak

Berdasarkan latar belakang masalah di atas, peneliti memberikan rumusan masalah "Apakah sentra bahan alam berpengaruh terhadap Kemampuan Sains anak Kelompok B RA Roudlotul Mujtahidin Tahun Pelajaran 2016/2017?”

Berdasarkan rumusan masalah tersebut, peneliti ini bertujuan sebagai berikut : “ untuk mengetahui pengaruh sentra bahan alam terhadap Kemampuan Sains anak pada Kelompok B RA Roudlotul Mujtahidin Tahun Pelajaran 2016/2017.”

\section{METODE PENELITIAN}

Rancangan penelitian adalah rencana dan sruktur penyelidikan yang disusun sedemikian rupa sehingga peneliti akan memperoleh jawaban untuk pertanyaan-pertanyaan penelitiannya. Berdasarkan permasalahan dan tujuan penelitian, maka penelitian ini menggunakan metode penelitian kuantitatif dengan jenis penelitiannya adalah penelitian Eksperimen. Penelitian ini menggunakan desain penelitian Pre-Experimental Designs dengan menggunakan One-Group Pre-Test-Post-Test Designs.

Metode ini digunakan karena penelitian ini bertujuan untuk melihat seberapa besar pengaruh penerapan Pembelajaran Sentra Bahan Alam Terhadap Perkembangan Kemampuan Sains pada anak kelompok B RA Roudlotul Mujtahidin sebelum dan sesudah diberi perlakuan. Berikut bagan penelitiannya menurut Arikunto Suharsimi ${ }^{5}$ :

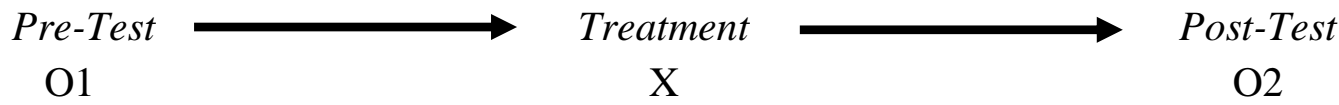

\section{Bagan 3.1 Rancangan Penelitian}

\footnotetext{
3 Hanafi, M. Zakaria, Implementasi Metode Sentra dalam Pengembangan Kecerdasan Majemuk Anak Usia Dini, (Yogyakarta: Deepublish, 2014), 56

${ }^{4}$ Ibid, 58

${ }^{5}$ Suharsimi, Arikunto, Penelitian Tindakan kelas, (Jakarta: Bumi Aksara, 2006), 85
} 
Dari bagan diatas dapat dapat dikethui prosedur penelitian ini sebagai berikut:

1. Memberikan $\mathrm{O}_{1}$ yaitu pre-test untuk mengukur Perkembangan Kemampuan Sains sebelum diberikan treatment berupa penerapan Pembelajaran Sentra Bahan Alam.

2. Memberikan X yakni perlakuan (treatment) Pembelajaran Sentra Bahan Alam kepada anak atau subyek untuk jangka waktu tertentu.

3. Memberikan $\mathrm{O}_{2}$ yaitu pos- test untuk mengukur Perkembangan Kemampuan Sains anak setelah pemberian tretment yakni penerapan Pembelajaran Sentra Bahan Alam.

4. Membandingkan $\mathrm{O}_{1}$ dengan $\mathrm{O}_{2}$ untuk mengetahui adanya perubahan yang terjadi setelah diberikan treatment berupa penerapan Pembelajaran Sentra Bahan Alam terhadap Perkembangan Kemampuan Sains pada anak kelompok B.

Arikunto berpendapat "populasi merupakan keseluruhan subyek penelitian". Sedangkan menurut Sugiyono menjelaskan populasi adalah wilayah generalisasi yang terdiri atas subyek yang mempunyai kuantitas dan karakteristik tertentu yang ditetapkan oleh peneliti untuk dipelajari kemudian ditarik kesimpulannya"7. Berdasarkan pendapat tersebut diatas dapat disimpulkan populasi adalah keseluruhan subyek penelitian yang memiliki ciriciri yang akan diteliti. Populasi dari penelitian ini adalah anak kelompok B RA Roudlotul Mujtahidin Jrambe tahun pelajaran 2016/2017 dengan jumlah anak sebanyak 26 anak.

Variabel penelitian adalah subyek penelitian, atau apa yang menjadi titik perhatian suatu penelitian $^{8}$. Berdasarkan judul, dalam penelitian ini ada dua variabel yaitu:

1. Variabel Bebas yaitu variabel yang memberikan pengaruh terhadap variabel lainnya. Dalam penelitian ini yang dikategorikan variabel bebas adalah pembelajaran sentra bahan alam.

2. Variabel Terikat yaitu variabel yang dipengaruhi variabel bebas. Dalam penelitian ini yang dikategorikan sebagai variabel terikat adalah perkembangan kemampuan sains.

Menurut Arikunto, validitas adalah suatu ukuran yang menunjukkan tingkat-tingkat kevalidan atau kesahan suatu instrumen ${ }^{9}$. Sedangkan menurut Sugiyono (2010: 173) bahwa instrumen dikatakan valid jika instrumen tersebut dapat digunakan untuk mengukur apa yang seharusnya diukur. Instrumen yang akan digunakan untuk mengukur pada saat penelitian harus menunjukkan tingkat kesahan dan dapat mengukur apa yang seharusnya diukur ${ }^{10}$. Dalam penelitian ini, lembar observasi disusun dengan menggunakan content validity yang disusun berdasarkan rancangan/program yang telah ada yaitu Kurikulum Taman Kanakkanak tahun 2013 dengan uji validitas item. Dalam penelitian ini media yang digunakan adalah media realia atau obyek nyata.

Sedangkan reliabilitas menurut Arikunto, menunjuk pada satu pengertian bahwa suatu instrumen cukup dapat dipercaya untuk digunakan sebagai alat pengumpul data karena instrumen terebut sudah baik. Penelitian ini menggunakan pengujian reliabilitas dengan

\footnotetext{
${ }^{6}$ Ibid, 130

${ }^{7}$ Sugiyono, Metode Penelitian Pendidikan Pendekatan Kuantitatif, Kualitatif, dan R \& D, (Bandung: Alfabeta, 2010), 117

${ }^{8}$ Suharsimi, Arikunto, Penelitian Tindakan kelas, (Jakarta: Bumi Aksara, 2006), 118

${ }^{9}$ Ibid, 169

${ }^{10}$ Sugiyono, Metode Penelitian Pendidikan Pendekatan Kuantitatif, Kualitatif, dan R \& D, (Bandung: Alfabeta, 2010), 173
} 
internal consistency yang dilakukan dengan mencobakan instrumen sekali saja dengan mencari reliabilitas pengamatan (observasi) ${ }^{11}$.

Pengumpulan data merupakan langkah yang penting dalam penelitian, karena pada umumnya data dikumpulkan dan digunakan untuk menguji hipotesis yang telah dirumuskan. Menurut Arikunto, menyebutkan bahwa macam-macam pengumpulan data meliputi penggunaan tes, angket, wawancara, observasi, dan dokumentasi. Teknik pengumpulan data yang digunakan dalam penelitian ini adalah observasi. Observasi yang sistematis dilakukan pengamat dengan menggunakan pedoman sebagai instrumen pengamatan ${ }^{12}$.

Dari segi proses pengamatan pengumpulan data, observasi dapat dibedakan menjadi participant observation dan non participant observation ${ }^{13}$. Pada penelitian ini menggunakan teknik observasi secara partisipatif, dalam observasi partisipatif pengamat ikut serta dalam kegiatan yang sedang berlangsung. Pada observasi partisipatif individu-individu yang diamati tidak tahu bahwa mereka sedang diobservasi sehinga situasi dan kegiatan akan berjalan lebih wajar. Namun, dalam hal ini pengamat harus melakukan dua kegiatan sekaligus yakni sebagai pengamat dan ikut serta melakukan kegiatan. Pada penelitian ini, observasi dilakukan saat sebelum dan sesudah pembelajaran sentra bahan alam diterapkan.

Sugiyono menjelaskan bahwa dalam penelitian kuantitatif, analisis data merupakan kegiatan setelah pengumpulan data dari seluruh responden atau sumber data lain yang terkumpul. Kegiatan dalam analisis data adalah mengelompokkan data berdasarkan variabel dan jenis responden, mentabulasi data berdasarkan variabel dari seluruh responden, menyajikan data tiap variabel yang diteliti, melakukan perhitungan untuk menjawab rumusan masalah, dan melakukan perhitungan untuk menguji hipotesis. Sedangkan data dalam suatu penelitian terdiri dari 4 macam yakni data nominal, ordinal, interval dan rasio ${ }^{14}$.

Dalam penelitian ini data yang diperoleh berupa data ordinal dan tidak berdistribusi normal, sehingga analisis statistik yang digunakan adalah statistic non-parametris. Hal ini sesuai dengan pendapat Sugiyono (2010: 150) statistic non-parametris digunakan untuk menganalisis data yang tidak dilandasi persyaratan data harus berdistribusi normal. Uji statistic non-parametris yang digunakan adalah uji Wilcoxon Matched Pairs Test yang dalam pelaksanaanya menggunakan tabel penolong ${ }^{15}$. Karena sampel yang digunakan dalam penelitian ini lebih besar dari 25 yakni 26 anak dimana mendekati data normal maka digunakan rumus z dalam pengujiannya atau untuk mencari harga muntlak. Rumus z tersebut adalah:

Dimana:

$$
\mathrm{Z}=\frac{T-\mu_{\tau}}{\sigma_{\tau}}
$$

$\mathrm{T}=$ jumlah jenjang/rangking yang kecil

$\mu_{\tau}=\frac{n(n+1)}{4}$

\footnotetext{
${ }^{11}$ Suharsimi, Arikunto, Penelitian Tindakan kelas, (Jakarta: Bumi Aksara, 2006), 178

${ }^{12}$ Ibid, 22

${ }^{13}$ Sugiyono, Metode Penelitian Pendidikan Pendekatan Kuantitatif, Kualitatif, dan $R \& D$, (Bandung: Alfabeta, 2010), 204

${ }^{14}$ Ibid, 207

${ }^{15}$ Ibid, 151
} 


$$
\sigma_{\tau}=\sqrt{\frac{n(n+1)(2 n+1)}{24}}
$$

Metode uji jenjang bertanda Wilcoxon dimaksudkan untuk mengetahui arah dan ukuran perbedaan. Langkah awal penggunaan uji jenjang bertanda Wilcoxon adalah menentukan kriteria signifikan perbedaan, misalnya dipilih $\alpha=5 \%$. Selanjutnya menentukan besar dan arah perbedaan hasil pengukuran $(\mathrm{T}-\mathrm{R})$, kemudian dilanjutkan dengan menentukan rank (pangkat) perbedaan mutlak.

Pangkat (rank) perbedaan mutlak dilakukan dengan ketentuan sebagai berikut:

a. Hasil pengukuran yang tidak menunjukkan perbedaan atau nol tidak diikutsertakan dalam pengolahan data.

b. Selisih paling kecil diberikan pangkat 1 , berturut-turut sampai selisih yang paling besar.

c. Menunjukkan sign rank positif dan negatif.

d. Menentukan kesimpulan dari pengujian hipotesis dengan jalan membandingkan Zhitung dan Ztabel untuk tingkat sigtifikansi $\alpha=5 \%$. Jika Zhitung $\geq$ Ztabel maka hipotesi nol ditolak, sebaliknya jika Zhitung < Ztabel maka hipotesis nol diterima.

\section{HASIL PENELITIAN DAN PEMBAHASAN}

Data Skor yang diperoleh dideskripsikan dengan mentabulasikan menurut masingmasing variabel, dengan bantuan program komputer SPSS diperoleh Skor tertinggi (max), Skor Terendah (min), Mean (Me), Varian (s), Modus (Mo), dan Median (Md).

Sebelum perlakuan (treatment) penerapan pembelajaran sentra bahan alam (pre-test)

Deskriptive Statistics

\begin{tabular}{|l|r|r|r|r|r|r|}
\hline & $\mathrm{N}$ & $\begin{array}{c}\text { Minimu } \\
\mathrm{m}\end{array}$ & $\begin{array}{r}\text { Maximu } \\
\mathrm{m}\end{array}$ & Mean & $\begin{array}{r}\text { Std.Deviatio } \\
\mathrm{n}\end{array}$ & $\begin{array}{c}\text { varianc } \\
\mathrm{e}\end{array}$ \\
\hline SKOR & 26 & 9,00 & 15,00 & 11,65 & 1,76505 & 3,115 \\
P1 & 26 & 1,00 & 4,00 & 35 &, 93890 &, 882 \\
P2 & 26 & 1,00 & 4,00 & 2,192 &, 72004 &, 518 \\
P3 & 26 & 1,00 & 3,00 & 3 &, 66216 &, 438 \\
P4 & 26 & 1,00 & 4,00 & 1,961 &, 73170 &, 535 \\
P5 & 26 & 1,00 & 3,00 & 5 &, 56704 &, 322 \\
P6 & 26 & 1,00 & 3,00 & 1,961 &, 51590 &, 266 \\
Valid N & 26 & & & 5 & & \\
(listwise) & & & & 1,846 & & \\
& & & & 2 & & \\
& & & & 1,807 & & \\
& & & & 1,884 & & \\
\end{tabular}

Sesudah perlakuan (treatment) penerapan pembelajaran sentra bahan alam (pre-test)

Deskriptive Statistics

\begin{tabular}{|l|r|r|r|r|r|r|}
\hline & $\mathrm{N}$ & $\begin{array}{c}\text { Minimu } \\
\mathrm{m}\end{array}$ & $\begin{array}{c}\text { Maximu } \\
\mathrm{m}\end{array}$ & Mean & $\begin{array}{r}\text { Std.Deviatio } \\
\mathrm{n}\end{array}$ & $\begin{array}{c}\text { varianc } \\
\mathrm{e}\end{array}$ \\
\hline SKOR & 26 & 1 & 4 & 2,92 &, 845 &, 714 \\
P1 & 26 & 1 & 4 & 3,19 &, 749 &, 562 \\
P2 & 26 & 2 & 4 & 3,08 &, 688 &, 474 \\
\hline
\end{tabular}




\begin{tabular}{|l|r|r|r|r|r|r|}
\hline P3 & 26 & 1 & 5 & 2,88 &, 993 &, 986 \\
P4 & 26 & 1 & 4 & 3,08 &, 796 &, 634 \\
P5 & 26 & 2 & 4 & 3,31 &, 788 &, 622 \\
P6 & 26 & 14 & 22 & 18,46 & 1,702 & 2,898 \\
Valid N & 26 & & & & & \\
(listwise) & & & & & & \\
\hline
\end{tabular}

Uji validitas menggunakan pengujian validitas konstruk, dengan cara mengkonsultasikan instrumen dengan dosen ahli (judgment experts). Setelah pengujian konstruk dari dosen ahli selesai, maka diteruskan uji coba instrumen. Setelah data ditabulasikan, maka pengujian validitas konstruk dilakukan dengan analisis faktor, yaitu dengan mengkorelasikan antar skor item instrumen, analisis faktor menggunakan rumus korelasi Product Moment.

Program yang digunakan adalah program SPSS. Teknik pengujian menggunakan korelasi Bivariate Pearson (Produk Momen Pearson). Analisis ini dengan cara mengkorelasikan masing-masing skor item dengan skor total. Skor total adalah penjumlahan dari keseluruhan item. Item-item pertanyaan yang berkorelasi signifikan dengan skor total menunjukkan item-item tersebut mampu memberikan dukungan dalam mengungkap apa yang ingin diungkap à Valid. Jika $r$ hitung $\geq r$ tabel (uji 2 sisi dengan sig. 0,05) maka instrumen atau item-item pertanyaan berkorelasi signifikan terhadap skor total (dinyatakan valid).

Pengujian reliabilitas instrumen dengan menggunakan rumus Alpha Cronbach karena instrumen penelitian ini berbentuk angket dan skala bertingkat. Jika nilai alpha $>0.7$ artinya reliabilitas mencukupi (sufficient reliability) sementara jika alpha $>0.80$ ini mensugestikan seluruh item reliabel dan seluruh tes secara konsisten memiliki reliabilitas yang kuat. Atau, ada pula yang memaknakannya sebagai berikut:

Jika alpha $>0.90$ maka reliabilitas sempurna. Jika alpha antara $0.70-0.90$ maka reliabilitas tinggi. Jika alpha $0.50-0.70$ maka reliabilitas moderat. Jika alpha $<0.50$ maka reliabilitas rendah. Jika alpha rendah, kemungkinan satu atau beberapa item tidak reliabel.

Dalam uji Uji Wilcoxon Signed Rank Peneliti ingin mengetahui Pengaruh Penerapan Pembelajaran Sentra Bahan Alam, terhadap Perkembangan Kemampuan Sains Anak untuk kebutuhan data, peneliti melakukan penilain sebelum (pre-test) dan sesudah (post-test) dilakukan treatment yaitu penerapan pembelajaran sentra bahan alam

\section{a. Output Ranks}

\section{Ranks}

\begin{tabular}{|ll|r|r|r|}
\hline & & \multicolumn{1}{|c|}{$\begin{array}{c}\text { Mean } \\
\text { Rank }\end{array}$} & \multicolumn{1}{c|}{ Sum of Ranks } \\
\hline Sesudah Perlakuan- & Negatif Ranks & $0^{\mathrm{a}}$ &, 00 &, 00 \\
Sebelum perlakuan & Positiv Ranks & $26^{\mathrm{b}}$ & 13,50 & 351,00 \\
& Ties & $0^{\mathrm{c}}$ & & \\
& Total & 26 & & \\
\hline
\end{tabular}

a. Sesudah Perlakuan < Sebelum Perlakuan

b. Sesudah Perlakuan $>$ Sebelum Perlakuan 


\section{c. Sesudah Perlakuan $=$ Sebelum Perlakuan}

Output pertama Ranks

1. Negative Ranks atau selisih (negative) antara penerapan pembelajaran sentra bahan alam untuk pre-test dan post-test adalah 0, baik nilai N, Mean Rank dan Sum of Ranks adalah 0 menunjukkan tidak ada penurunan (pengurangan) dari nilai pre-test ke nilai post-test

2. Positive Ranks atau selisih(positif) antara pre-test dan post-test, menunjukkan angka 26 positif $(\mathrm{N})$ yang artinya ke 26 Siswa mengalami peningkatan skor (nilai) dari nilai pre-test ke nilai post-test, Mean Rank atau rata-rata peningkatan sebesar 13.50, sedangkan Sum of Ranks atau jumlah rangking positif sebesar 351,00

3. Ties adalah nilai kesamaan pre-test dan post-test, disini menunjukkan nilai 0 , yang artinya tidak ada nilai yang sama antara pre-test dan post-test

Dalam Uji Hipotesis menggunkan SPSS didapatkan output "Test Statistics", dasar pengambilan keputusan yang digunakan dalam uji Wilcoxon adalah :

1. Jika nilai Asymp. Sig (2-tailed) lebih kecil dari $<0.05$ maka Ha diterima

2. Sebaliknya jika nilai Asymp. Sig (2-tailed lebih besar dari >0,005 maka Ha ditolak

\begin{tabular}{|l|r|}
\hline & $\begin{array}{r}\text { Sesudah Perlakuan- } \\
\text { Sebelum Perlakuan }\end{array}$ \\
\hline Z & $-4,477^{\mathrm{b}}$ \\
Asymp.Sig.(2-tailed) &, 000 \\
\hline
\end{tabular}

a. Wilcoxon Signed Ranks Test

b. Based on negative ranks

Berdasarkan output Test Statistics diatas nilai Asymp. Sig (2-tailed) adalah 0, Karena nilai Asymp. Sig (2-tailed) lebih kecil dari 0.005 maka Ha diterima, yang artinya ada perbedaan Nilai atau skor Perkembangan Kemampuan Sains Anak untuk pre-test dan posttest, sehingga dapat disimpulkan ada Pengaruh Penerapan Pembelajaran Sentra Bahan Alam terhadapa perkembangan Kemampuan Sains Anak

\section{KESIMPULAN DAN SARAN}

Kesimpulan :

Dari hasil penelitian dan pembahasan dapat diambil kesimpulan sebagai berikut :

1. Angka pada Negative Ranks atau selisih (negative), N, Mean Rank dan Sum of Ranks adalah 0 , yang artinya antara penerapan pembelajaran sentra persiapan untuk pre-test dan post-test menunjukkan tidak ada penurunan (pengurangan) dari nilai pre-test ke nilai post-test

2. Positive Ranks atau selisih (positif) antara pre-test dan post-test, menunjukkan angka 26 positif $(\mathrm{N})$ yang artinya ke 26 siswa mengalami peningkatan skor (nilai) dari nilai pretest ke nilai post-test, Mean Rank atau rata-rata peningkatan sebesar 13.50, sedangkan Sum of Ranks atau jumlah rangking positif sebesar 351,00, Menunjukkan peningkatan skor perkembangan Kemampuan Sains anak sebelum dan sesudah menerapkan pembelajaran Sentra Bahan Alam. 
3. Ties adalah nilai kesamaan pre-test dan post-test, disini menunjukkan nilai 0, yang artinya tidak ada nilai yang sama antara pre-test dan post-test ini menunjukkan ada perbedaan nilai perkembangan Kemampuan Sains sebelum penerapan sentra dan sesudah penerapan Sentra Bahan Alam.

4. Nilai atau skor yang diambil dari sebelum dan sesudah diterapkan pembelajaran sentra bahan alam menunjukkan peningkatan dari semua siswa

5. Nilai peningkatan perkembangan Kemampuan Sains dari ke 26 siswa yang telah dilakukan penerapan pembelajaran Sentra Bahan Alam rata-rata skor atau nilai meningkat 13.50

6. Test Statistics diatas nilai Asymp. Sig (2-tailed) adalah 0, Karena nilai Asymp. Sig (2tailed) lebih kecil dari 0.005 maka ada pengaruh yang signifikan perkembangan Kemampuan Sains anak sebelum dan sesuadah penerapan pembelajaran Sentra Bahan Alam

7. Dilihat dari hasil analisis angka-angka statistik yang dihasilkan melalui Uji Wilcoxon hasilnya adalah bahwa Penerapan Pembelajaran Sentra Bahan Alam berpengaruh terhadap peningkatan perkermbangan Kemampuan Sains anak di RA Roudlotul Mujtahidin Jrambe

8. Pembelajaran Sentra Bahan Alam sangat efektif untuk meningkatkan perkembangan Kemampuan Sains anak khusunya

\section{Saran}

Berdasarkan kesimpulan dan pembahasan hasil penelitian maka dikemukakan beberapa saran sebagai berikut:

1. Bagi Guru

a. Sebaiknya menerapkan pembelajaran sentra khususnya sentra Bahan Alam dalam meningkatkan aspek perkembangan anak

b. Pembelajaran sentra sangat efektif pada anak usia dini hendaknya guru mengembangkan pembelajaran sentra-sentra yang lain.

2. Bagi Peneliti selanjutnya

a. Penelitian hanya terbatas pada pembelajaran sentra Bahan Alam dan aspek perkembangan Kemampuan Sains disarankan untuk melakukan penelitian terhadap pembelajaran sentra dan aspek perkembangan lainnya

b. Dapat melakukan penelitian dengan pengaruh salah satu pembelajaran sentra terhadap beberapa aspek perkembangan anak usia dini

\section{DAFTAR PUSTAKA}

Hanafi, M. Zakaria. 2014. Implementasi Metode Sentra dalam Pengembangan Kecerdasan Majemuk Anak Usia Dini. Yogyakarta: Deepublish

Hardjadinata, Yohana. 2009. Batitaku Mandiri.Jakarta: Dian Rakyat

Hirai Maya. 2010. Kreasi Origami Favorit. Jakarta:Kawan Pustaka

Julius Hambali, Siskandar, dan Mohamad Rohmad, 1996. Psych HYPERLINK "http://idid.facebook.com/pages/Teens-n-Kids/199015246131"Teens 'n Kids, Google di unduh tgl 9 Juli 2011 
Kurrien Zakiah, 2004. Memberdayakan Anak Belajar. Surabaya: Plan

Lara Fridani, M.Psych HYPERLINK "http://id-id.facebook.com/pages/Teens Kids/199015246131"Teens 'n Kids, Google di unduh tgl 9 Juli 2011

Martuti, 2005.Mengelola PAUD. Yugjakarta: Kreasi Wacana

Muhammad, As'adi. 2009. Panduan Praktis Menggambar Dan Mewarnai Untuk Anak. Jogjakarta:Power Books

Montolalu B.E.F. 2005.Bermain dan Permaianan Anak. Jakarta: UT

Nurani Sujiono, 2009. Konsep dasar Pendidikan Anak Usia Dini. Jakarta: PT Indek

Patmonodewo, 1994. Buku Ajar Pendidikan Prasekolah. Jakarta: Depdikbud

Subinarto, 2005. Jurus Jitu Mengasah Otak SI Kecil. Bandung: Media inc

Sudono Bambang, 1995. Metode Pengembangan Fisik. Jakarta: UT

Suharsimi, Arikunto, dkk., 2006. Penelitian Tindakan Kelas, Jakarta, Bumi Aksara.

Sugiyono. 2010. Metode Penelitian Pendidikan Pendekatan Kuantitatif, Kualitatif, dan R \& $D$. Bandung: Alfabeta

Sukidin, dkk., 2007, Manajemen Penelitian Tindakan Kelas, Surabaya, Insan Cendekia.

Sudijono, BambangDkk. 2005 MetodePengembanganFisik. Jakarta: UT . 2007 Metode Pengembangan Fisik. Jakarta: UT

Suratno. 2005. Pengembangan Kreativitas Anak Usia Dini. Jakarta: Depdiknas

Yamin Martinis, Sanan jamilah Sabri, 2010. Panduan Pendidikan Anak Usia Dini, Jakarta: Gaung Persada 